\title{
Thermotolerance in Lettuce Seeds: Association with Ethylene and Endo- $\beta$-mannanase
}

\author{
Warley M. Nascimento, ${ }^{1}$ Daniel J. Cantliffe, ${ }^{2}$ and Donald J. Huber \\ University of Florida, Institute of Food and Agricultural Sciences, Horticultural Sciences Department, \\ 1251 Fifield Hall, PO Box 110690, Gainesville, FL 32611-0690
}

\begin{abstract}
ADDITIONAL INDEX wORDs. Lactuca sativa, thermodormancy, endosperm weakening, enzyme activity
Abstract. Weakening of the endosperm tissue around the radicle tip before radicle protrusion and a potential role of endo- $\beta$-mannanase during germination of lettuce seeds (Lactuca sativa $\mathrm{L}$.) at high temperature $\left(35^{\circ} \mathrm{C}\right)$ were investigated. Seeds from the thermotolerant genotypes 'Everglades' and PI 251245 had greater endo- $\beta$-mannanase activity before radicle protrusion at $35{ }^{\circ} \mathrm{C}$ than the thermosensitive genotypes 'Dark Green Boston', 'Valmaine' and 'Floricos 83'. Thermotolerant genotypes also generated more ethylene at high temperature. At $35{ }^{\circ} \mathrm{C}$, germination of 'Dark Green Boston' and 'Everglades' seeds produced at days/nights of $20 / 10{ }^{\circ} \mathrm{C}$ was $10 \%$ and $32 \%$, respectively, whereas germination of seeds produced at days/nights of $30 / 20{ }^{\circ} \mathrm{C}$ was $67 \%$ and $83 \%$, respectively. Higher endo- $\beta$-mannanase activity was observed before radicle protrusion in 'Dark Green Boston' seeds produced at $30 / 20{ }^{\circ} \mathrm{C}$ compared with those produced at $20 / 10^{\circ} \mathrm{C}$. A relationship between seed germination at high temperature, ethylene production, and an increase in endo$\beta$-mannanase activity before radicle protrusion was confirmed.
\end{abstract}

Under high temperatures, lettuce (Lactuca sativa) germination can be erratic or completely inhibited. The exact mechanism of thermoinhibition or thermodormancy is still debated. Some researchers reported that the lettuce endosperm layer mechanically restricts radicle protrusion, especially at high temperature (Halmer et al., 1976; Ikuma and Thimann, 1963). Sung et al. (1998a) concluded that the weakening of the lettuce endosperm layer was a prerequisite to radicle protrusion. Ikuma and Thimann (1963) proposed that the action of an enzyme produced by the embryo enabled the radicle tip to penetrate through the restricting tissues. Since lettuce endosperm cell walls are composed largely of galactomannans (Halmer et al., 1975), endo- $\beta$-mannanase might play an important role in weakening of the endosperm and subsequent radicle protrusion. Dutta et al. (1997) reported that a cell-wall-bound endo- $\beta$-mannanase was expressed in lettuce seed endosperm before radicle protrusion and was regulated by the same conditions that govern seed germination. These authors suggested that endo- $\beta$-mannanase was likely to be involved in the weakening of the lettuce endosperm cell walls during germination at high temperature $\left(32^{\circ} \mathrm{C}\right)$.

The critical maximum temperature for lettuce seed germination depends on genotype (Damania, 1986; Gray, 1975; Harrington and Thompson, 1952; Thompson et al., 1979). A wild plant accession, PI 251245, was identified to be a thermotolerant line (Bradford, 1985); however, the thermotolerance character was obscured by the environmental conditions under which the seeds developed (Nagata, personal communication). Thermotolerant cultivars have been developed (Guzman, 1986; Guzman and Zitter, 1983; Guzman et al., 1992); however, it is not understood how seeds inherit the ability to germinate at high temperature.

During seed development, both genotype and environmental conditions may affect subsequent seed germination at high temperature (Drew and Brocklehurst, 1990; Gray et al., 1988; Steiner

Received for publication 6 July 1999. Accepted for publication 8 Mar. 2000. Florida Agricultural Experiment Station journal series R-06925. The cost of publishing this paper was defrayed in part by the payment of page charges. Under postal regulations, this paper therefore must be hereby marked advertisement solely to indicate this fact.

${ }^{1}$ Current address: EMBRAPA-Hortaliças, C. Postal 218, Brasília, DF 70359-970, Brazil.

${ }^{2}$ Corresponding author; e-mail djc@gnv.ifas.ufl.edu. and Opoku-Boateng, 1991). Lettuce seeds produced in hot climatic regions germinated better at high temperature (Damania, 1986; Harrington and Thompson, 1952) compared to seeds produced at lower temperature regimes. Under controlled conditions, Gray et al. (1988) verified that lettuce seeds produced at days/nights of $30 / 20^{\circ} \mathrm{C}$ germinated better at $30^{\circ} \mathrm{C}$ than seeds produced at $25 / 15^{\circ} \mathrm{C}$ or $20 / 10^{\circ} \mathrm{C}$. In another study, Sung et al. (1998a) reported that lettuce seeds matured at $30 / 20{ }^{\circ} \mathrm{C}$ had a greater germination percentage at high temperature than those matured at lower temperatures. These authors concluded that the thermotolerance character in lettuce seed was regulated by an interaction between genotype and temperature during seed development.

Several studies reported that ethylene synthesis was decreased by high temperature during imbibition of lettuce seeds (Abeles, 1986; Burdett, 1972a, 1972b; Dunlap and Morgan, 1977; Khan and Huang, 1988). In addition, exogenous ethylene overcame the inhibitory effect of high temperature on lettuce seed germination (Abeles, 1986; Abeles and Lonski, 1969; Burdett, 1972b; Dunlap and Morgan, 1977; Fu and Yang, 1983; Huang and Khan, 1992; Keys et al., 1975; Khan and Prusinski, 1989; Negm et al., 1972; Rao et al., 1975; Saini et al., 1986). The exact mechanism of ethylene action during lettuce seed germination is not well understood. Therefore, the objective of this research was to determine if there is an association among ethylene, endo- $\beta$ mannanase, endosperm weakening, and germination of thermotolerant and thermosensitive lettuce genotypes at high temperature.

\section{Materials and Methods}

Plant material. Five lettuce genotypes varying in levels of thermotolerance were used in this study: 'Dark Green Boston' (DGB), 'Valmaine' (VAL), and 'Floricos 83' (FLO) (thermosensitive), and 'Everglades' (EVE) and PI 251245 (PI) (thermotolerant). Thermotolerance was defined in this study as the ability of seeds to germinate $>90 \%$ at $35^{\circ} \mathrm{C}$ in light (Guzman et al., 1992; Sung, 1996). All seeds were produced in the same season and region of the San Joaquin Valley, California, in 1994. Seeds were stored at $5 \%$ moisture in a sealed container at $10{ }^{\circ} \mathrm{C}$ and $40 \%$ relative humidity $(\mathrm{RH})$ until used. 
Seed maturation Study. Lettuce plants of thermosensitive DGB and thermotolerant EVE were produced under greenhouse conditions until flowering and then transferred to growth chambers at $12 \mathrm{~h}$ days $/ 12 \mathrm{~h}$ nights of $20 / 10^{\circ} \mathrm{C}$ or $30 / 20^{\circ} \mathrm{C}$ with a daily $12 \mathrm{~h}$ photoperiod according to methods used by Sung et al. (1998a). At maturity, seeds were harvested, threshed, and cleaned manually. Seeds were dried to $5 \%$ moisture then stored at $10{ }^{\circ} \mathrm{C}$ and $45 \%$ RH until used. DBG and EVE were chosen in this study because DGB was used as part of the genetic background of EVE (Guzman et al., 1992).

SEED Germination. Four replications of 25 seeds each were placed on two layers of $5.0-\mathrm{cm}$ diameter germination paper (Anchor Paper, Hudson, Wis.), moistened with $3 \mathrm{~mL}$ of distilled water. Blotters were covered with $5.5-\mathrm{cm}$ glass petri dish lids and incubated at $20 \%$ or $35^{\circ} \mathrm{C}$ under constant fluorescent light $(\approx 26$ $\mu \mathrm{mol} \cdot \mathrm{m}^{-2} \cdot \mathrm{s}^{-1}$ ) on a one-dimensional thermogradient bar (Type DB 5000, Van Dok \& De Boer, B.V., Holland). In another study, EVE seeds were incubated at $20,27.5$, or $35^{\circ} \mathrm{C}$ under constant light or dark, using the same germination conditions described previously.

ENZYME ACTIVITY. A gel-diffusion assay (Downie et al., 1994; Still et al., 1997) was used to measure endo- $\beta$-mannanase (EC 3.2.1.78) activity during seed germination. Gel plates were prepared by dissolving $0.05 \%$ (w/v) galactomannan (locust bean gum, Sigma Chem. Co., St. Louis, Mo.) in incubation buffer ( 0.1 $\mathrm{M}$ citric acid, $0.2 \mathrm{M}$ sodium phosphate, $\mathrm{pH}$ 5.0), and stirred and heated for $30 \mathrm{~min}$. Afterward the solution was clarified by centrifugation at $11,000 g_{\mathrm{n}}$ for $15 \mathrm{~min}$ at $4{ }^{\circ} \mathrm{C}$. Phytagar (Gibco Lab., Grand Island, N.Y.) at $0.7 \%$ (w/v) was added to the clarified solution and stirred and heated to boiling. Thirty milliliters of the solution was dispensed into $150 \times 25 \mathrm{~mm}$ disposable plastic petri dishes (Falcon, Franklin Lakes, N.J.). After solidification, 32 wells per plate were made using a 2 -mm disposable plastic pipette and removing the excised gel by aspiration.

Twenty-eight whole individual endosperms or 14 radicle tips plus 14 remaining endosperms (referred to as lateral endosperm) from lettuce seeds imbibed at different temperatures for different periods of time were used on each plate. In one study, endosperm from seeds imbibed at 20 or $35^{\circ} \mathrm{C}$ was excised and enzyme activity measured at four different times: after $4 \mathrm{~h}$ of imbibition, $1 \mathrm{~h}$ before radicle protrusion, $1 \mathrm{~h}$ after radicle protrusion, and 24 $\mathrm{h}$ after imbibition. Radicle protrusion was determined previously in both temperatures for each genotype. Three replications were utilized for each treatment. Endosperms were excised by pressing the cotyledon end using the tip of a conical glass rod. Micropylar and lateral regions were separated with a surgical blade. For seeds incubated in the dark, endosperm excision was performed under a green safelight. Each endosperm, radicle tip, or lateral part was placed into an individual microtiter plate (Nalge Nunc, Naperville, Ill.) well containing $20 \mu \mathrm{L}$ of incubation buffer $(0.1 \mathrm{~m}$ citric acid, $0.2 \mathrm{~m}$ sodium phosphate, $\mathrm{pH} 5.0$ ) and incubated in the dark for 2 $\mathrm{h}$ at $20^{\circ} \mathrm{C}$.

After incubation, $10 \mu \mathrm{L}$ of buffer from each well was transferred to the gel-diffusion plates. Petri dishes were covered with a lid, wrapped in parafilm and incubated for $24 \mathrm{~h}$. Gels were stained by adding $10 \mathrm{~mL}$ of Congo Red (Sigma) in water $(0.4 \%$, $\mathrm{w} / \mathrm{v}$ ) to each plate. Plates were shaken for $20 \mathrm{~min}$ at $60 \mathrm{rpm}$ during staining. The Congo red solution was decanted and the gel was gently washed (1 min) in distilled water, then $10 \mathrm{~mL}$ of the citratephosphate at $\mathrm{pH} 7.0$ was added. After 2 to $3 \mathrm{~min}$ on an orbital shaker at $60 \mathrm{rpm}$, the buffer was decanted. Plates were scanned within 5 to 10 min using a Hewlett Packard Scan Jet 3c/T
(Greenley, Colo.). The diameters of cleared areas were measured using MacRhizo (Regent Instruments Inc., Quebec, Canada) software. Enzyme activity was calculated from standard curves using regression analysis. Purified endo- $\beta$-mannanase (Megazyme, County Wicklow, Ireland) was used as a standard.

ETHYLENE DETERMination. Three replications of $0.2 \mathrm{~g}$ of dry seeds was placed on two layers of $3.0 \mathrm{~cm}$ diameter germination paper (Anchor Paper) which were at the base of $38 \mathrm{~mL}$ volume vials sealed with rubber septa. The seeds in the vials were moistened with $3 \mathrm{~mL}$ of distilled water, and then incubated under the same conditions as the standard germination procedures. After 3, 6, 9, 12, 18 or $24 \mathrm{~h}$ of imbibition, ethylene evolution was determined. In one study, ethylene was determined after $10 \mathrm{~h}$ of imbibition (before radicle protrusion). A one milliliter gas sample was withdrawn using a gas-tight hypodermic syringe. After sample withdrawal, the vials were flushed with air and sealed again for additional sampling. Ethylene was assayed using a Series II Hewlett-Packard 5890 Series gas chromatograph (Hewlett-Packard Co., Atlanta, Ga.) equipped with an alumina column and a flame ionization detector. The carrier gas was nitrogen and the column temperature was $100{ }^{\circ} \mathrm{C}$.

EXPERIMENTAL DESIGN AND STATISTICAL ANALYSIS. Ethylene evolution, enzyme activity, and germination tests were conducted using a completely randomized design, with three replications per treatment. Germination percentages were transformed to a square root arc sine basis before statistical analysis. Analysis of variance was performed by means of SAS software (SAS Inst., Inc., 1987). Treatment means were separated by Duncan's multiple range test. In analyzing the effect of light and temperature interactions, treatment means were separated by LSD. Correlation analyses were performed and Pearson correlation coefficients were generated using PROC CORR (SAS, Inst., Inc. 1987).

\section{Results and Discussion}

GERMINATION AND ENDO- $\beta$-MANNANASE ACTIVITY. Germination was $\geq 96 \%$ for all of the genotypes incubated at $20^{\circ} \mathrm{C}$ (Table 1 ). The onset of seed germination (visible radicle protrusion in 50\% of the seeds) varied from 13 (PI) to $20 \mathrm{~h}$ (VAL). At $20^{\circ} \mathrm{C}$, no endo$\beta$-mannanase activity was observed after $4 \mathrm{~h}$ of imbibition (Table 1). Halmer (1989) observed endo- $\beta$-mannanase activity at $24^{\circ} \mathrm{C}$ in lettuce seeds only after $6 \mathrm{~h}$ of seed imbibition, and suggested that endo- $\beta$-mannanase production was dependent on completion of transcriptional events during the 6-h lag phase. Enzyme activity in the present experiment was observed $1 \mathrm{~h}$ before radicle protrusion in seeds of all genotypes except DGB (Table 1).

At $35^{\circ} \mathrm{C}$, only the thermotolerant genotypes (EVE and PI) germinated $>90 \%$ (Table 2). At this temperature, seeds from the PI germinated after $6 \mathrm{~h}$, whereas seeds from FLO that germinated required $16 \mathrm{~h}$ on average. DGB seeds germinated only $4 \%$, and VAL did not germinate. Enzyme activity was not detected before radicle protrusion at $35^{\circ} \mathrm{C}$ in the thermosensitive DGB, VAL, and FLO genotypes (Table 2). This may have been related to their inability to germinate at $35^{\circ} \mathrm{C}$. Halmer (1989) reported that endo$\beta$-mannanase is synthesized de novo. Endo- $\beta$-mannanase activity in the PI after $12 \mathrm{~h}$ at $20^{\circ} \mathrm{C}$ was similar to that of seeds imbibed at $35^{\circ} \mathrm{C}$ for $4 \mathrm{~h}$ (Table 2). Similarly, EVE germinated $8 \mathrm{~h}$ earlier at $35^{\circ} \mathrm{C}$ compared to $20^{\circ} \mathrm{C}$. Presumably, differences observed in endo- $\beta$-mannanase activity at $4 \mathrm{~h}$ would account for faster germination of EVE or PI. Dutta et al. (1997) observed a suppression of endo- $\beta$-mannanase activity in 'Pacific' lettuce seeds at $32{ }^{\circ} \mathrm{C}$, while at $25^{\circ} \mathrm{C}$ endosperm cell walls exhibited active autolysis. 
Table 1 . Seed germination and endo- $\beta$-mannanase activity in the whole endosperm of lettuce genotypes imbibed in constant light at $20{ }^{\circ} \mathrm{C}$.

\begin{tabular}{|c|c|c|c|c|c|c|}
\hline \multirow[b]{3}{*}{ Genotype $^{y}$} & \multirow[b]{3}{*}{$\begin{array}{c}\text { Germination } \\
(\%)\end{array}$} & \multirow[b]{3}{*}{$\begin{array}{l}50 \% \text { Radicle } \\
\text { protrusion }(\mathrm{h})\end{array}$} & \multicolumn{4}{|c|}{ Mannanase activity $\left(\mathrm{pmol} \cdot \mathrm{min}^{-1}\right)^{\mathrm{z}}$} \\
\hline & & & \multicolumn{4}{|c|}{ Radicle protrusion } \\
\hline & & & $\begin{array}{l}4 \mathrm{~h} \text { of } \\
\text { imbibition }\end{array}$ & $\begin{array}{c}1 \mathrm{~h} \\
\text { before }\end{array}$ & $\begin{array}{l}1 \mathrm{~h} \\
\text { after }\end{array}$ & $\begin{array}{c}24 \mathrm{~h} \text { of } \\
\text { imbibition }\end{array}$ \\
\hline DGB & $100 \mathrm{a}^{\mathrm{x}}$ & $19 \mathrm{~b}$ & $\mathrm{ND}^{\mathrm{w}}$ & ND & ND & $2 \mathrm{de}$ \\
\hline VAL & $98 \mathrm{ab}$ & $20 \mathrm{~b}$ & ND & $0.8 \mathrm{~b}$ & $3.0 \mathrm{ab}$ & $12 \mathrm{~d}$ \\
\hline FLO & $96 \mathrm{~b}$ & $16 \mathrm{ab}$ & ND & $1.2 \mathrm{~b}$ & $2.6 \mathrm{~b}$ & $248 \mathrm{a}$ \\
\hline EVE & $100 \mathrm{a}$ & $18 \mathrm{~b}$ & ND & $2.7 \mathrm{a}$ & $3.5 \mathrm{a}$ & $110 \mathrm{bc}$ \\
\hline PI & $100 \mathrm{a}$ & $13 \mathrm{a}$ & ND & $0.4 \mathrm{~b}$ & $1.5 \mathrm{c}$ & $152 \mathrm{~b}$ \\
\hline
\end{tabular}

${ }^{\mathrm{z}}$ Enzyme activity was measured $1 \mathrm{~h}$ before and $1 \mathrm{~h}$ after radicle protrusion in each genotype. Also, after 4 and $24 \mathrm{~h}$ of imbibition.

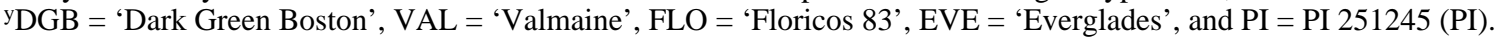

'Mean separation within columns by Duncan's multiple range test, $P \leq 0.05$.

${ }^{\mathrm{w}} \mathrm{ND}=$ not detectable.

Table 2. Seed germination and endo- $\beta$-mannanase activity in the whole endosperm of lettuce genotypes imbibed in constant light at $35{ }^{\circ} \mathrm{C}$.

\begin{tabular}{|c|c|c|c|c|c|c|}
\hline \multirow[b]{3}{*}{ Genotype $^{y}$} & \multirow[b]{3}{*}{$\begin{array}{c}\text { Germination } \\
(\%)\end{array}$} & \multirow[b]{3}{*}{$\begin{array}{l}50 \% \text { Radicle } \\
\text { protrusion }(\mathrm{h})\end{array}$} & \multicolumn{4}{|c|}{ Mannanase activity $\left(\mathrm{pmol} \cdot \mathrm{min}^{-1}\right)^{\mathrm{z}}$} \\
\hline & & & \multicolumn{4}{|c|}{ Radicle protrusion } \\
\hline & & & $\begin{array}{c}4 \mathrm{~h} \text { of } \\
\text { imbibition }\end{array}$ & $\begin{array}{c}1 \mathrm{~h} \\
\text { before }\end{array}$ & $\begin{array}{l}1 \mathrm{~h} \\
\text { after }\end{array}$ & $\begin{array}{c}24 \mathrm{~h} \text { of } \\
\text { imbibition }\end{array}$ \\
\hline$\overline{\text { DGB }}$ & $4 c^{x}$ & $14 \mathrm{a}$ & $\mathrm{ND}^{\mathrm{w}}$ & ND & ND & $2 \mathrm{~d}$ \\
\hline VAL & $0 \mathrm{c}$ & --- & ND & ND & --- & ND \\
\hline FLO & $26 \mathrm{~b}$ & $16 \mathrm{a}$ & ND & ND & $13.5 \mathrm{a}$ & $255 \mathrm{a}$ \\
\hline EVE & $96 \mathrm{a}$ & $10 \mathrm{~b}$ & $1.1 \mathrm{a}$ & 1.2 & $2.7 \mathrm{~b}$ & $25 \mathrm{c}$ \\
\hline PI & $100 \mathrm{a}$ & $6 \mathrm{c}$ & $1.5 \mathrm{a}$ & ND & ND & $173 \mathrm{~b}$ \\
\hline
\end{tabular}

${ }^{\mathrm{z}}$ Enzyme activity was measured $1 \mathrm{~h}$ before and $1 \mathrm{~h}$ after radicle protrusion in each genotype. Also, after 4 and $24 \mathrm{~h}$ of imbibition.

'DGB = 'Dark Green Boston', VAL = 'Valmaine', FLO = 'Floricos 83', EVE = 'Everglades', and PI = PI 251245 (PI).

${ }^{x}$ Mean separation within columns by Duncan's multiple range test, $P \leq 0.05$.

${ }^{\mathrm{w}} \mathrm{ND}=$ not detectable.

Possibly at $35{ }^{\circ} \mathrm{C}$, protein synthesis is adversely affected or factors involved in the regulation of endo- $\beta$-mannanase production by the endosperm are inhibited in thermosensitive genotypes such as DGB, but not in thermotolerant EVE and PI.

A low (basal) amount of enzyme activity was detected before radicle protrusion at $35^{\circ} \mathrm{C}$ in the thermotolerant EVE and PI genotypes. However, although mannanase was detected after $4 \mathrm{~h}$ imbibition, no mannanase activity was detected in the PI immediately $(1 \mathrm{~h})$ before and after radicle protrusion. Perhaps, a lower requirement of mannanase was enough to lead to endosperm weakening which permitted the PI to germinate at $35^{\circ} \mathrm{C}$. In the present study, using a single seed assay method, levels of as little as $1 \mathrm{pmol} \cdot \mathrm{min}^{-1}$ of endo- $\beta$-mannanase could be measured. Low pmol levels of the enzyme appeared to be adequate in many cases for endosperm weakening, consequently leading to seed germination. During the endosperm mobilization phase of germination, large amounts of endo- $\beta$-mannanase were detected.

The level of endosperm resistance during puncture tests with lettuce depends on genotype (Sung et al., 1998b). Using the same seed lots and genotypes as in the present research, Sung et al. (1998b) verified that thermotolerant genotypes had lower endosperm resistance than the thermosensitive types. Thermotolerant genotypes appeared to have weakened endosperm cell walls and depleted stored reserves (Sung, 1996; Sung et al., 1998a). Combining the aforementioned results with those in the present study, a relationship between seed germination at high temperature, lower resistance to endosperm rupture, and increased endo- $\beta$ mannanase activity before radicle protrusion was evident.

In tomato (Lycopersicon esculentum Mill.), a positive relationship between germination ability at low temperature and endo- $\beta$-mannanase activity in six progeny lines has been observed (Leviatov et al., 1995). The authors found that an increase in endo- $\beta$-mannanase activity in the micropylar region of the endosperm is essential for radicle protrusion, and the degree of

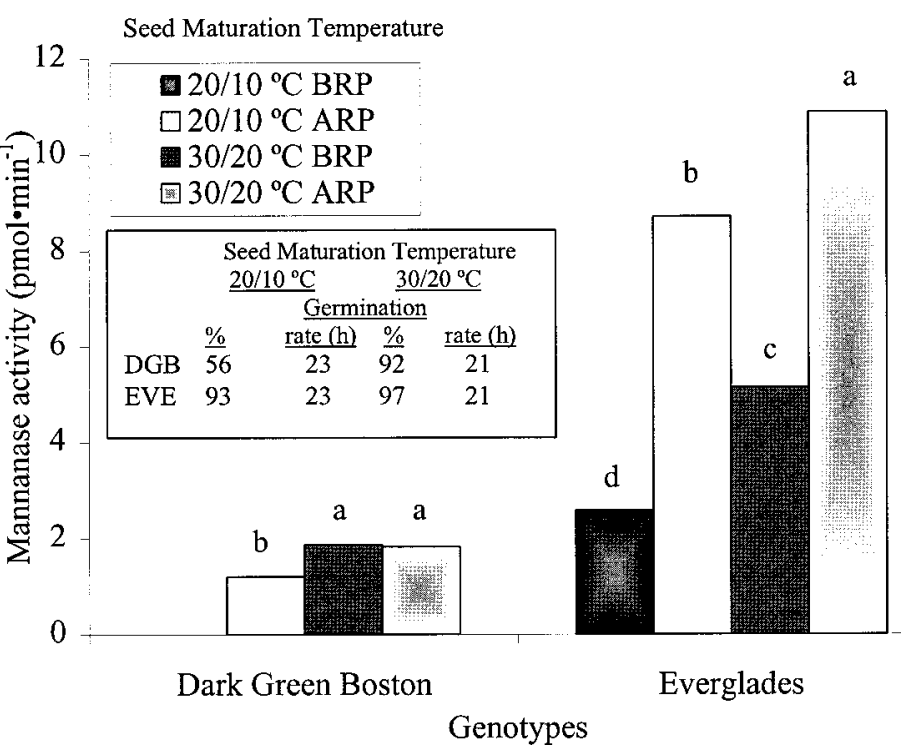

Fig. 1. Germination and endo- $\beta$-mannanase activity of whole-lettuce endosperm at $20{ }^{\circ} \mathrm{C}$ of 'Dark Green Boston' (DGB) and 'Everglades' (EVE) seeds developed at two different day/night temperature regimes. Rate $=$ time to $50 \%$ radicle protrusion, $\mathrm{BRP}=1 \mathrm{~h}$ before radicle protrusion, $\mathrm{ARP}=1 \mathrm{~h}$ after radicle protrusion. Mean separation within genotypes by Duncan's multiple range test, $P \leq 0.05$. 


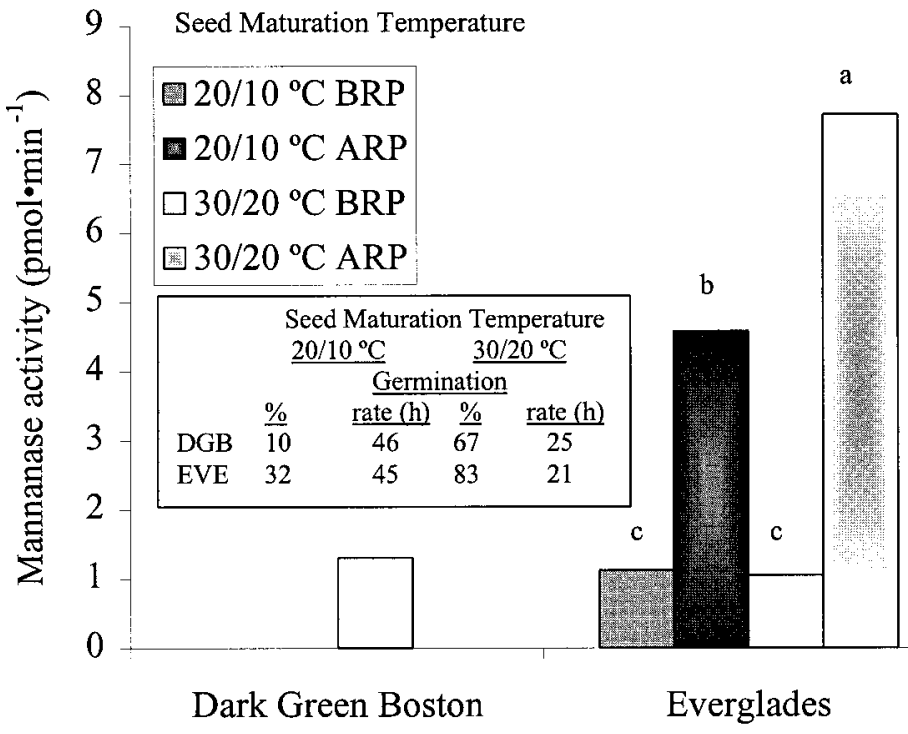

Genotypes

Fig. 2. Germination and endo- $\beta$-mannanase activity of whole-lettuce endosperm at $35{ }^{\circ} \mathrm{C}$ of 'Dark Green Boston' (DGB) and 'Everglades' (EVE) seeds developed at two different day/night temperature regimes. Rate $=$ time to $50 \%$ radicle protrusion, $\mathrm{BRP}=1 \mathrm{~h}$ before radicle protrusion, $\mathrm{ARP}=1 \mathrm{~h}$ after radicle protrusion. Mean separation within genotypes by Duncan's multiple range test, $P \leq 0.05$.

enzyme activity at low temperature is correlated with the coldtolerant germinating lines.

Sung et al. (1998a) reported that lettuce endosperm cell walls in front of the radicle from DGB and EVE seeds matured at high temperature were degraded more rapidly than those from seeds matured at low temperatures. In the present study, DGB seeds developed under high temperatures $\left(30 / 20{ }^{\circ} \mathrm{C}\right)$ germinated at a higher percentage at $20^{\circ} \mathrm{C}$ than seeds developed under lower temperatures $\left(20 / 10^{\circ} \mathrm{C}\right)$ (Fig. 1). EVE seeds developed either at $30 / 20^{\circ} \mathrm{C}$ or $20 / 10{ }^{\circ} \mathrm{C}$ had similar germination percentages at 20 ${ }^{\circ} \mathrm{C}$ (Fig. 1). At $20^{\circ} \mathrm{C}$, seeds from both genotypes developed under $20 / 10^{\circ} \mathrm{C}$ had $50 \%$ radicle protrusion after $23 \mathrm{~h}$, and seeds matured at $30 / 20{ }^{\circ} \mathrm{C}$ germinated after $21 \mathrm{~h}$. Only $56 \%$ of DGB seeds developed under $20 / 10^{\circ} \mathrm{C}$ germinated at $20^{\circ} \mathrm{C}$. The seed lot germinated $97 \%$ at $18^{\circ} \mathrm{C}$, thus, in this lot some of the seeds were thermosensitive even at $20{ }^{\circ} \mathrm{C}$.

In the present research, germination at $35^{\circ} \mathrm{C}$ of DGB produced at $20 / 10{ }^{\circ} \mathrm{C}$ was $10 \%$, whereas seeds produced at $30 / 20^{\circ} \mathrm{C}$ germinated $67 \%$ (Fig. 2). EVE seeds produced at $20 / 10^{\circ} \mathrm{C}$ and $30 / 20^{\circ} \mathrm{C}$ germinated at $32 \%$ and $83 \%$, respectively, at $35^{\circ} \mathrm{C}$ (Fig. 2). Seeds from both genotypes produced at $20 / 10{ }^{\circ} \mathrm{C}$ required $\approx 20$ more hours to germinate than seeds matured at $30 / 20^{\circ} \mathrm{C}$. Thus, seeds matured at high temperature exhibited higher germination regardless of genotype.

Higher enzyme activity was observed $1 \mathrm{~h}$ before radicle protrusion in DGB seeds produced under $30 / 20{ }^{\circ} \mathrm{C}$ compared with those produced at $20 / 10{ }^{\circ} \mathrm{C}$. This was especially true when seeds were germinated at $35^{\circ} \mathrm{C}$ (Fig. 2). Enzyme activity could not be detected before radicle protrusion in seeds of DGB developed at $20 / 10^{\circ} \mathrm{C}(10 \%$ total germination). Thus, seed maturation at high tem- perature partially overcame the inhibitory effect of high temperature on DGB germination, possibly due to the observed increase in endo- $\beta$-mannanase activity during germination.

ETHYLENE PROduction. High temperatures inhibit ethylene production in lettuce seeds and exogenous ethylene overcomes the inhibitory effect (Abeles, 1986; Khan and Prusinski, 1989; Saini et al., 1989). In the current study, ethylene evolution during germination was measured to determine possible differences in ethylene production among the thermosensitive and thermotolerant genotypes. At $20^{\circ} \mathrm{C}$, ethylene production was not detected before $6 \mathrm{~h}$ of imbibition (Fig. 3). Ethylene was detected from germinating seeds of FLO and PI, at 6 and $9 \mathrm{~h}$ respectively, from the initiation of imbibition. After $9 \mathrm{~h}$ from the initiation of imbibition, ethylene production was observed in all genotypes, except DGB, which had the lowest ethylene production rate during a 24-h imbibition period. The highest amount of ethylene was detected after radicle protrusion in all the genotypes, regardless of temperature. Khan (1994) reported that little or no ethylene was detected in lettuce seed before germination, but relatively large amounts of ethylene were produced at the time of radicle protrusion. Perhaps only low amounts of ethylene are observed before radicle protrusion because ethylene is trapped beneath the integuments of the seed, and the rupture of endosperm and seed coat during radicle protrusion allows built-up ethylene to be released. Also, exchange of all gases may be impeded by the seed coverings, especially at high temperatures, thus reducing ethylene production. Prusinski and Khan (1990) reported that lettuce seed coverings might create a hypoxic environment unfavorable for conversion of ACC to ethylene. Further investigations are needed to determine the amount of ethylene trapped inside a lettuce seed and the amount needed for seed germination.

At $35^{\circ} \mathrm{C}$, the first detectable ethylene production occurred between 9 and $12 \mathrm{~h}$ in FLO, EVE, and PI (Fig. 4). Moreover, ethylene production in thermotolerant genotypes was greater during seed germination at high temperature than in the

\footnotetext{
Fig. 3. Ethylene evolution in lettuce seeds incubated in light at $20^{\circ} \mathrm{C}$. DGB $=$ 'Dark Green Boston', VAL = 'Valmaine', FLO = 'Floricos 83', EVE = 'Everglades', and PI $=$ PI251245. Radicle protrusion $(\mathrm{RP})=50 \%$ of those seeds that germinated. Mean separation within each interval by Duncan's multiple range test, $P \leq 0.05$.
}

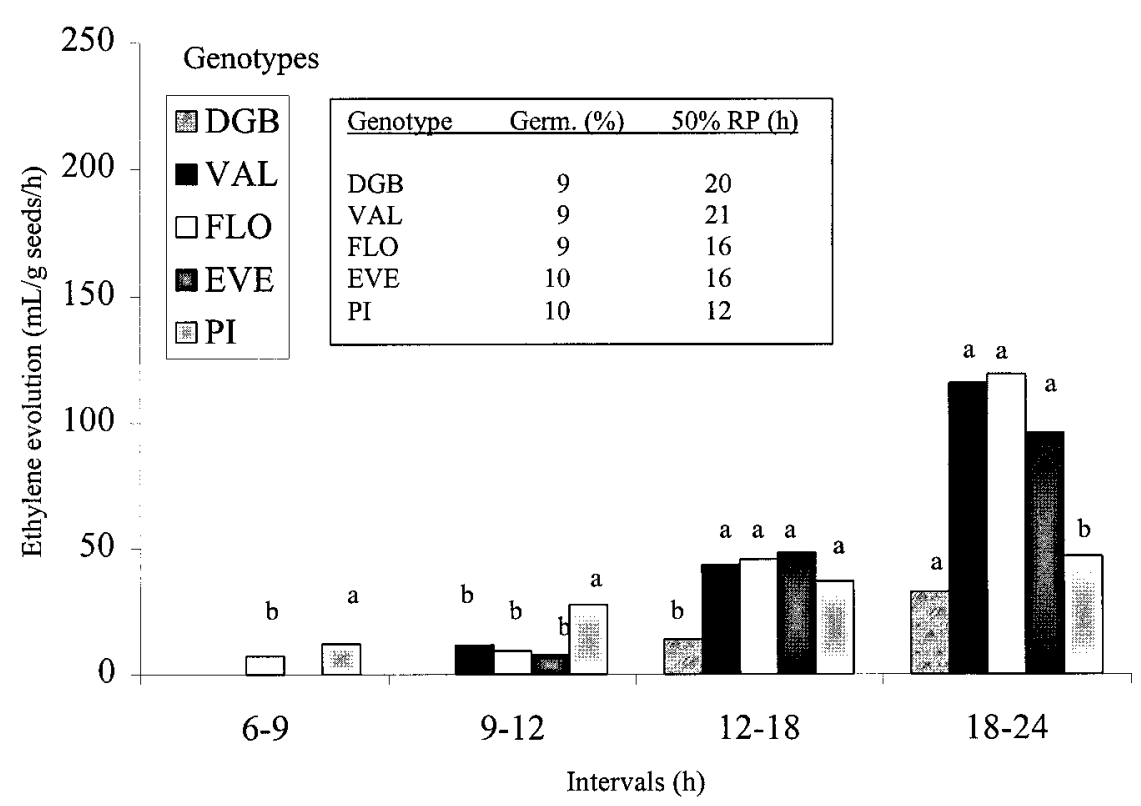




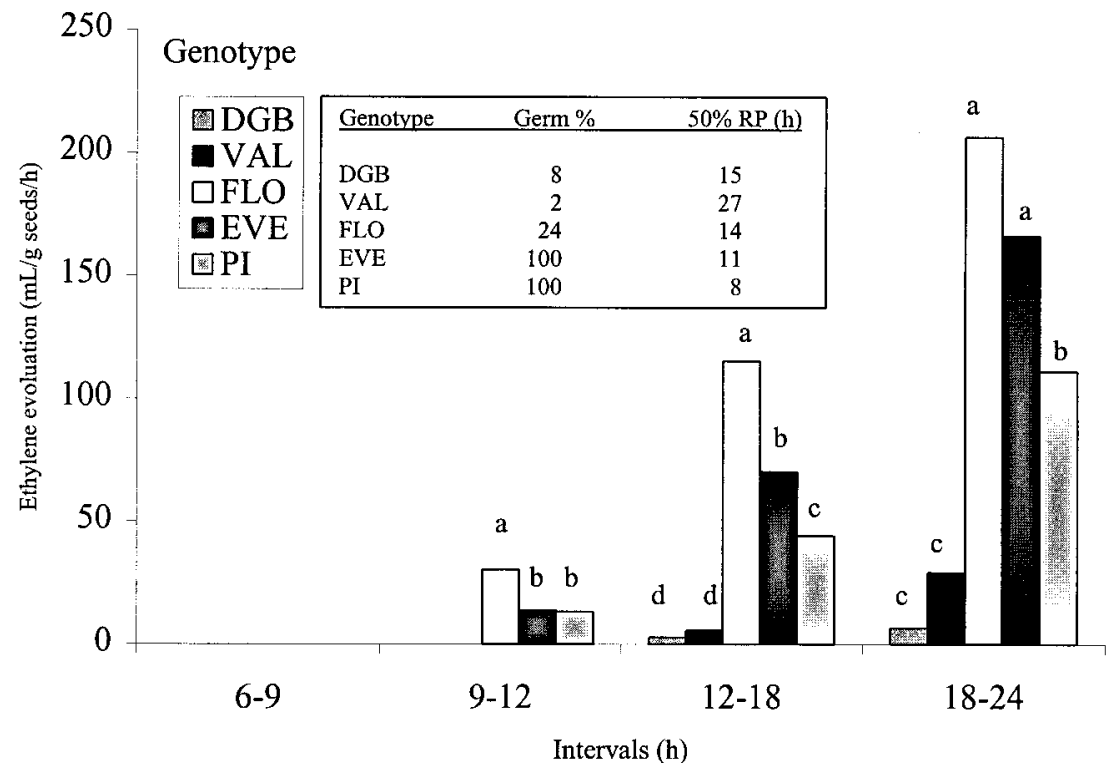

Fig. 4. Ethylene evolution in lettuce seeds incubated in light at $35^{\circ} \mathrm{C}$. DGB = 'Dark Green Boston', VAL = 'Valmaine', FLO = 'Floricos 83', EVE = 'Everglades', and PI $=$ PI251245. Radicle protrusion $(\mathrm{RP})=50 \%$ of those seeds that germinated. Mean separation within each interval by Duncan's multiple range test, $P \leq 0.05$.

thermosensitive genotypes. Conversely, seeds from thermosensitive DGB and VAL had the lowest ethylene production rate at $35^{\circ} \mathrm{C}$. These results agree with Prusinski and Khan (1990), who reported that the ability of lettuce genotypes to produce ethylene during high temperature stress corresponded with their ability to germinate. They suggested this as a criterion to select thermotolerant lettuce cultivars. The thermotolerant genotypes that produced more ethylene at high temperature (Fig. 4) also exhibited more endo- $\beta$-mannanase activity and germinated earlier (Table 2). Thus, an association between ethylene evolution, endo- $\beta$-mannanase activity before radicle protrusion, and seed germination at high temperature was verified.

At high temperature, red light improves germination of lettuce seed (Blaauw-Jasen, 1981; Evenari et al., 1953; Georghiou and
Thanos, 1983; Heydecker and Joshua, 1977; Saini et al., 1989; Vidaver and Hsiao, 1974). EVE, a thermotolerant lettuce genotype, germinated $>90 \%$ at temperatures up to $35^{\circ} \mathrm{C}$ in light (Guzman et al., 1992). However, germination of EVE decreased when seeds were imbibed under high temperature in the dark (Sung, 1996). Thus, there is an important interaction between light and high temperature, which may be mediated by the phytochrome system (Fielding et al., 1992; Taylorson and Hendriks, 1972).

Regulation of germination at high temperature by ethylene is also enhanced in light (Dunlap and Morgan, 1977), suggesting that the process may also be mediated by phytochrome (Negm and Smith, 1978). In addition, high temperature (35 to $40{ }^{\circ} \mathrm{C}$ ) may inhibit ethylene production in various plant tissues (Yu et al., 1980). Thus, another study was conducted to investigate the possible correlation between endo- $\beta$-mannanase activity, ethylene production, and germination of EVE seeds imbibed under light and dark conditions at three temperatures. A significant interaction for all the aforementioned parameters was observed (Table 3). At $20{ }^{\circ} \mathrm{C}$, seeds imbibed in either light or dark germinated $100 \%$ after $16 \mathrm{~h}$. At $27.5^{\circ} \mathrm{C}$, seeds germinated after $13 \mathrm{~h}$, and germination was $100 \%$ and $92 \%$ in light and dark, respectively. At $35^{\circ} \mathrm{C}$, seeds imbibed in light germinated at $94 \%$, whereas those in dark germinated at only $7 \%$; both began germinating at $13 \mathrm{~h}$. Before radicle protrusion, endo- $\beta$-mannanase activity assayed in the micropylar endosperm region was higher at $20^{\circ} \mathrm{C}$ in the dark or at $27.5^{\circ} \mathrm{C}$ in light (Table 3 ). With increasing temperature during imbibition in dark, enzyme activity decreased in the micropylar endosperm region before radicle protrusion. At $35^{\circ} \mathrm{C}$ in the dark, no enzyme activity could be detected before radicle protrusion.

Endo- $\beta$-mannanase activity was also observed in the lateral endosperm before radicle protrusion and increased markedly after radicle protrusion (Table 3). Bewley and Halmer (1980/81) reported that lettuce seeds imbibed in light produced high amounts

Table 3. Ethylene production, mannanase activity, and germination of 'Everglades' lettuce seeds incubated at different conditions.

\begin{tabular}{|c|c|c|c|c|c|c|c|}
\hline \multirow{2}{*}{\multicolumn{2}{|c|}{$\begin{array}{l}\text { Temp } \\
\left({ }^{\circ} \mathrm{C}\right)\end{array}$}} & \multirow[b]{2}{*}{$\begin{array}{c}\text { Germination } \\
(\%)\end{array}$} & \multicolumn{4}{|c|}{ Mannanase activity $\left(\mathrm{pmol} \cdot \mathrm{min}^{-1}\right)$} & \multirow[b]{2}{*}{$\begin{array}{c}\text { Ethylene } \\
(\mathrm{pL} / \mathrm{g} \text { seeds } / \mathrm{h})^{\mathrm{z}}\end{array}$} \\
\hline & & & $\begin{array}{l}1 \mathrm{~h} \text { before } \\
\text { radicle } \\
\text { protrusion }\end{array}$ & $\begin{array}{l}1 \mathrm{~h} \text { after } \\
\text { radicle } \\
\text { protrusion }\end{array}$ & $\begin{array}{l}1 \mathrm{~h} \text { before } \\
\text { radicle } \\
\text { protrusion }\end{array}$ & $\begin{array}{l}1 \mathrm{~h} \text { after } \\
\text { radicle } \\
\text { protrusion }\end{array}$ & \\
\hline & Light & 100 & 1.2 & 2.2 & 1.1 & 61.0 & 934 \\
\hline & Dark & 100 & 1.6 & 2.2 & 1.2 & 28.0 & 896 \\
\hline \multirow[t]{2}{*}{35} & Light & 94 & 1.2 & 1.6 & 1.1 & 15.4 & 1066 \\
\hline & Dark & 7 & $\mathrm{ND}^{\mathrm{y}}$ & 2.7 & ND & 9.8 & 0 \\
\hline LSD ( & $0.05)$ & 5.6 & 0.14 & 0.18 & 0.23 & 0.14 & 64 \\
\hline \multicolumn{8}{|c|}{ Significance } \\
\hline & $\mathrm{emp}(\mathrm{T})$ & $* *$ & $* *$ & $* *$ & $* *$ & $* *$ & $* *$ \\
\hline
\end{tabular}

${ }^{\mathrm{z}}$ Ethylene was determined after $10 \mathrm{~h}$ of imbibition (before radicle protrusion).

${ }^{\mathrm{y} D}=$ not detectable.

${ }^{* * *}$ Significant at $P<0.01$ by $\mathrm{F}$ test. 
of endo- $\beta$-mannanase, but this was only observed after radicle protrusion. Seeds imbibed in the dark produced little endo- $\beta$ mannanase (Halmer et al., 1976), but that was not true for this study at $27.5^{\circ} \mathrm{C}$. Thus, conditions where phytochrome-induced lettuce seed germination was inhibited also led to a reduction in endo- $\beta$-mannanase activity. For example, at $35^{\circ} \mathrm{C}$ in the dark, germination was $7 \%$, and essentially no enzyme activity could be detected before radicle protrusion. Incubation of 'Pacific' lettuce seeds in the dark at $32{ }^{\circ} \mathrm{C}$ resulted in no germination and almost complete suppression of endo- $\beta$-mannanase (Dutta et al., 1997). Endo- $\beta$-mannanase activity before radicle protrusion in the light was lower at $35^{\circ} \mathrm{C}$ compared to $27.5^{\circ} \mathrm{C}$ (Table 3 ).

Ethylene production by seeds imbibed in light was slightly more than those imbibed in dark at each temperature. Saini et al. (1989) reported that in 'Grand Rapids' lettuce, ethylene evolution in red light-incubated seeds began to increase $2 \mathrm{~h}$ before radicle protrusion, whereas the dark-incubated seeds produced a low and constant amount of ethylene at $32^{\circ} \mathrm{C}$. Ethylene production during seed germination at $35^{\circ} \mathrm{C}$ was lower than at $27.5^{\circ} \mathrm{C}$, particularly in the dark. The optimum temperature for ethylene production in some fruit tissue is near $30^{\circ} \mathrm{C}$, and starts to decline in temperatures $>30{ }^{\circ} \mathrm{C}$ until it ceases near $40^{\circ} \mathrm{C}$ (Abeles et al., 1992). In lettuce, a decrease in ethylene synthesis was also observed under high temperature during seed imbibition (Abeles, 1986; Burdett, 1972b; Dunlap and Morgan, 1977; Khan and Huang, 1988). In the present study, ethylene production was not observed at $35^{\circ} \mathrm{C}$ in the dark after $10 \mathrm{~h}$ of imbibition. The ethylene produced at $10 \mathrm{~h}$ (i.e., before radicle protrusion) correlated with mannanase activity in the micropylar region before radicle protrusion $(r=0.85)$, and with germination $(r=0.90)$. Consequently, a high correlation $(r=0.96)$ was observed between mannanase activity in the micropylar region before radicle protrusion and seed germination.

Are ethylene and mannanase two factors that might regulate the thermotolerance character in lettuce seeds? Seeds from thermotolerant genotypes had higher endo- $\beta$-mannanase activity before radicle protrusion and greater ethylene evolution. Also, regardless of genotype, seeds matured at high temperature produced more enzyme activity, and more seeds germinated at high temperature than those matured at low temperature. Conditions that inhibited seed germination, such as high temperature in thermosensitive genotypes, or high temperature under dark conditions in thermotolerant genotypes, also reduced endo- $\beta$ mannanase activity and ethylene production. The puncture tests and anatomical studies using these same lettuce genotypes (Sung, 1996; Sung et al., 1998b) provide further evidence that weakening of the endosperm tissue around the radicle tip before radicle protrusion was related to the regulation of lettuce germination at high temperature. Thus, genotype and seed maturation temperature could overcome high temperature inhibition by increased endo- $\beta$-mannanase activity and/or ethylene production. A relationship between seed germination at high temperature and an increase in ethylene evolution and endo- $\beta$-mannanase activity before radicle protrusion was established in this study.

\section{Literature Cited}

Abeles, F.B. 1986. Role of ethylene in Lactuca sativa cv. 'Grand Rapids' seed germination. Plant Physiol. 81:780-787.

Abeles, F.B. and J. Lonski. 1969. Stimulation of lettuce seed germination by ethylene. Plant Physiol. 44:277-280.

Abeles, F.B., P.W. Morgan, and M.E. Saltveit, Jr. 1992. Ethylene and plant biology, $2^{\text {nd }}$ ed. Academic Press, San Diego.
Bewley J.D. and P. Halmer. 1980/81. Embryo-endosperm interactions in the hydrolysis of lettuce seed reserves. Israel J. Bot. 29:118-132.

Blaauw-Jansen, G. 1981. Differences in the nature of thermodormancy and far-red dormancy in lettuce seeds. Physiol. Plant 53:553-557.

Bradford, K.J. 1985. Germination improvement and avoidance of thermodormancy through osmotic treatment of seeds. Annual Reports, 1984-1985, to the California Iceburg Lettuce Advisory Board's Research Program, Published by California Lettuce Advisory Board. p. 61-72.

Burdett, A.N. 1972a. Antagonistic effects of high and low temperature pretreatments on the germination and pregermination ethylene synthesis of lettuce seeds. Plant Physiol. 50:201-204.

Burdett, A.N. 1972b. Ethylene synthesis in lettuce seeds: Its physiological significance. Plant Physiol. 50:719-722.

Damania, A.B. 1986. Inhibition of seed germination in lettuce at high temperature. Seed Res. 14:177-184.

Downie, B, H.W.M. Hilhorst, and J.D. Bewley. 1994. A new assay for quantifying endo-b-mannanase activity using Congo red dye. Phytochemistry 36:829-835.

Drew, R.L.K. and P.A. Brocklehurst. 1990. Effects of temperature of mother-plant environment on yield and germination of seeds of lettuce (Lactuca sativa). Ann. Bot. 66:63-71.

Dunlap, J.R. and P.W. Morgan. 1977. Reversal of induced dormancy in lettuce by ethylene, kinetin, and gibberellic acid. Plant Physiol. 60:222224.

Dutta, S., K.J. Bradford, and D.J. Nevins. 1997. Endo- $\beta$-mannanase present in cell wall extracts of lettuce endosperm prior to radicle emergence. Plant Physiol. 133:155-161.

Evenari, M., G. Neumann, and G. Stein. 1953. Factors modifying the influence of light on germination. Nature 172:452-453.

Fielding, A., D.N. Kristie, and P. Dearman. 1992. The temperature of Pfr action governs the upper temperature limit for germination in lettuce. Photochem. Photobiol. 56:623-627.

Fu, J.R. and S.F. Yang. 1983. Release of heat pretreatment-induced dormancy in lettuce seeds by ethylene or cytokinin in relation to the production of ethylene and the synthesis of 1-aminocyclopropane-1carboxylic acid during germination. Plant Growth Regulat. 2:185-192. Georghiou, K and C.A. Thanos. 1983. Phytochrome control of skotodormancy release in 'Grand Rapids' lettuce achenes. Physiol. Plant 57:352-356.

Gray, D. 1975 Effects of temperature on the germination and emergence of lettuce (Lactuca sativa L.) varieties. HortScience. 50:349-361.

Gray, D., D.C.E. Wurr, J.A. Ward, and J.R. Fellows. 1988. Influence of post-flowering temperature on seed development, and subsequent performance of crisp lettuce. Ann. Appl. Biol. 113:391-402.

Guzman, V.L. 1986. 'Short Guzmaine', 'Tall Guzmaine', and 'Floriglade': Three cos lettuce cultivars resistant to lettuce mosaic viruses. Univ. Florida Agr. Expt. Sta., Inst. Food and Agr. Sci., Gainesville. Circ. S326.

Guzman, V.L., R.T. Nagata, L.E. Datnoff, and R.N. Raid. 1992. 'Florida 202' and 'Everglades': New butterhead lettuce cultivars adapted to Florida. HortScience. 27:852-853.

Guzman, V.L. and T.A. Zitler. 1983. 'Floricos': A cos lettuce cultivar resistance to two viruses for Florida organic soils. Univ. Florida Agr. Expt. Sta., Inst. Food and Agr. Sci., Gainesville. Circ. S-305.

Halmer, P. 1989 De novo synthesis of mannanase by the endosperm of Lactuca sativa. Phytochemistry 28:371-378.

Halmer, P., J.D. Bewley, and T.A. Thorpe. 1975. Enzyme to break down lettuce endosperm cell wall during gibberellin-and-light-induced germination. Nature 258:716-718.

Halmer, P., J.D. Bewley, and T.A. Thorpe. 1976. An enzyme to degrade lettuce endosperm cell walls: Appearance of a mannanase following phytochrome- and gibberellin-induced germination. Planta 130:189196.

Harrington, J.F. and R.C. Thompson. 1952. Effect of variety and area of production on subsequent germination of lettuce seed at high temperature. J. Amer. Soc. Hort. Sci. 59:445-450.

Heydecker, W. and A. Joshua. 1977. Alleviation of the thermodormancy 
of lettuce (Lactuca sativa L.) seeds. HortScience. 52:87-98.

Huang, X.L. and A.A. Khan. 1992. Alleviation of thermoinhibition in preconditioned lettuce seeds involves ethylene, not polyamine biosynthesis. J. Amer. Soc. Hort. Sci. 117:841-845.

Ikuma, H. and K.V. Thimann. 1963. The role of seed-coats in germination of photosensitive lettuce seeds. Plant Cell Physiol. 4:169-185.

Keys, R.D., O.E. Smith, J. Kumamoto, and J.L. Lyon. 1975. Effect of gibberellic acid, kinetin, and ethylene plus carbon dioxide on the thermodormancy of lettuce seed (Lactuca sativa L. cv. Mesa 659). Plant Physiol. 56:826-829.

Khan, A.A. 1994. ACC-derived ethylene production, a sensitive test for seed vigor. J. Amer. Soc. Hort. Sci. 119:1083-1090.

Khan, A.A. and K.L. Huang. 1988. Synergistic enhancement of ethylene production and germination with kinetin and 1-aminocyclopropane-1carboxylic acid in lettuce seeds exposed to salinity stress. Plant Physiol. 87:847-852.

Khan, A.A. and J. Prusinski. 1989. Kinetin enhanced 1-aminocyclopropane-1-carboxylic acid utilization during alleviation of high temperature stress in lettuce seeds. Plant Physiol. 91:733-737.

Leviatov, S., O. Shoseyov, and S. Wolf. 1995. Involvement of endomannanase in the control of tomato seed germination under low temperature conditions. Ann. Bot. 76:1-6.

Negm, F.B. and O.E. Smith. 1978. Effects of ethylene and carbon dioxide on the germination of osmotically inhibited lettuce seed. Plant Physiol. 62:473-476.

Negm, F.B., O.E. Smith, and J. Kumamoto. 1972. Interaction of carbon dioxide and ethylene in overcoming thermodormancy of lettuce seeds. Plant Physiol. 49:869-872.

Prusinski, J. and A.A. Khan. 1990. Relationship of ethylene production to stress alleviation in seeds of lettuce cultivars. J. Amer. Soc. Hort. Sci. 115:294-298.

Rao, V.S., N. Sankhla, and A.A. Khan. 1975. Additive and synergistic effect of kinetin and ethrel on germination, thermodormancy, and polyribosome formation in lettuce seeds. Plant Physiol. 56:263-266.

Saini, H.S., E.D. Consolacion, P.K. Bassi, and M.S. Spencer. 1986.
Requirement for ethylene synthesis and action during relief of thermoinhibition of lettuce seed germination by combinations of gibberellic acid, kinetin, and carbon dioxide. Plant Physiol. 81:950953.

Saini, H.S., E.D. Consolacion, P.K. Bassi, and M.S. Spencer. 1989. Control processes in the induction and relief of thermoinhibition of lettuce seed germination: Actions of phytochrome and endogenous ethylene. Plant Physiol. 90:311-315.

SAS Inst., Inc. 1987. SAS/STAT user's guide. Release 6.03 ed. SAS Inst., Cary, N.C.

Steiner, J.J. and Opoku-Boateng. 1991. Natural season-long and diurnal temperature effects on lettuce seed production and quality. J. Amer. Soc. Hort. Sci. 116:396-400.

Still, D.W., P. Dahal, and K.J. Bradford. 1997. A single-seed assay for endo- $\beta$-mannanase activity from tomato endosperm and radicle tissues. Plant Physiol. 113:13-20.

Sung, Y. 1996. Identification and characterization of thermotolerance in lettuce seed germination. PhD diss., Univ. of Florida, Gainesville.

Sung, Y., D.J. Cantliffe, and R.T. Nagata. 1998a. Seed developmental temperature regulation of thermotolerance in lettuce. J. Amer. Soc. Hort. Sci. 123:700-705.

Sung, Y., D.J. Cantliffe, and R.T. Nagata. 1998b. Using a puncture test to identify the role of seed coverings on thermotolerant lettuce seed germination. J. Amer. Soc. Hort. Sci. 123:1102-1106.

Taylorson, R.B. and S.B. Hendricks. 1972. Interactions of light and temperature shift on seed germination. Plant Physiol. 49:127-130.

Thompson, P.A., A.S. Cox, and R.H. Sanderson. 1979. Characterization of the germination responses to temperature of lettuce (Lactuca sativa L.) achenes. Ann. Bot. 43:319-334.

Vidaver, W. and A.I.H. Hsiao. 1974. Actions of gibberellic acid and phytochrome on the germination of 'Grand Rapids' lettuce seeds. Plant Physiol. 53:266-268.

Yu, Y.B., D.O. Adams, and S.F. Yang. 1980. Inhibition of ethylene production by 2,4 dinitrophenol and high temperature. Plant Physiol. 66:286-290. 